\title{
Relações históricas entre Macau e as Filipinas: uma perspectiva portuguesa
}

\author{
José Manuel Garcia
}

Gabinete de Estudos Olisiponenses, Portugal

A partir de 1557, Macau se desarrolló como un puesto/establecimiento mercantil gracias a las actividades comerciales regulares entre Japón y China. Los españoles, radicados desde 1571 en Manila, iniciaron en 1582 una ruta comercial intermitente con Macau que fue considerada ilegal por las autoridades durante el periodo de la dinastía filipina en Portugal (1580-1640). Sin embargo, los intercambios económicos y religiosos entre las dos ciudades siempre fueron tolerados. La llegada de los holandeses a Oriente multiplicó la colaboración económica y militar entre Macau y Manila, como defensa ante la amenaza de los nuevos competidores europeos. Las relaciones entre las dos ciudades se rompieron tras la aclamación de dom João IV en Macau, en 1642.

Palabras Clave: Macau, Manila, China, Filipinas, comercio hispano-luso, expansión portuguesa, expansión española.

Macau became, since 1557, a commercial centre that flourished, due to regular mercantile activities between Japan and China. The Spanish, settled in Manila since 157, began in 1582 an endless commercial route between Manila and Macau, which was considered illegal by the authorities during the period of the philippine dynasty that ruled Portugal (1580-1640). However, the economical and religious interchange between the two towns were tolerated in a way or another. The arrival of the Dutch to the east multiplied the economical and military cooperation, between Macau and Manila, having in mind the defence against the threat of the new European competitors. Only the acclamation of king Joano IV in Macau in 1642 stopped the relationship between the two towns.

Keywords: Macau. Manila. China. Philippines. Portuguese-spanish commerce. Portuguese expansion. Spanish expansion.

Em 1509, os portugueses chegaram a Malaca e a partir de então iniciaram um relacionamento com o Sudeste Asiático e o Extremo Oriente que se prolongou na longa duração. As áreas da intervenção portuguesa em

1 Doutorado em História pela Universidade do Porto; e membro das Academia Portuguesa da História; Academia de Marinha e Sociedade de Geografia de Lisboa; pertenceu à direcção da Comissão Nacional para as Comemorações dos Descobrimentos Portugueses. Publica desde 1981 livros, artigos e obras e organiza exposições sobre temas relativos à História dos Descobrimentos e da Expansão Portuguesa no Mundo. 
múltiplas áreas dessa parte do Mundo centraram-se nas Molucas, no Japão e em Macau, sendo ainda de considerar a partir das duas últimas décadas do século XVI e até 1640 um relacionamento com as Filipinas a partir de Macau. Este último e importante relacionamento nem sempre tem sido devidamente considerado ou divulgado nas suas múltiplas facetas económicas, políticas e religiosas, que estão interligadas, pelo que considerámos oportuno apresentar aqui uma ampla perspectiva de síntese sobre tal matéria de acordo com algumas das mais importantes fontes portuguesas.

\section{Sobre o início das relações de Portugal com o Sudeste Asiático e o Extremo Oriente}

Para apreender os aspectos mais relevantes da História das relações entre Macau e as Filipinas importa começar por contextualizar brevemente a presença dos portugueses nestas regiões tão afastadas da Europa, começando desde logo por ter em conta o facto de ter sido em 16 de Março de 1521 que o português Fernão de Magalhães, então ao serviço de Castela, foi o primeiro dirigente de uma expedição naval europeia a chegar às Filipinas. A realização deste feito, que marca o início da História das relações destas ilhas com espanhóis e portugueses, foi o resultado de um desvio do percurso inicialmente previsto pelo famoso navegador, pois o seu objectivo consistia em ir às Molucas. Nestas ilhas, situadas a sul das Filipinas, os portugueses procediam ao comércio do cravo desde 1512, tendo construído em 1522 uma fortaleza-feitoria em Ternate para assim lograrem um melhor domínio do comércio local. ${ }^{2}$ Em contraponto com o sucesso obtido nas Molucas, e neste mesmo ano de 1522, os portugueses sofreram um severo revés nas suas aspirações mercantis ao serem obrigados a abandonar a China, para onde tinham começado a ir regularmente desde 1513. Ficavam assim frustradas as suas expectativas de aí virem a desenvolver negócios muito lucrativos, tendo-se por isso limitado na década seguinte a processar a um comércio entre as Molucas e Malaca, realizando para o efeito viagens em que se aproximaram das ilhas do sul das Filipinas quando seguiam a rota que passava por Bornéu. ${ }^{3}$

2 Garcia, José Manuel: A viagem de Fernão de Magalhães e os portugueses, Editorial Presença, Lisboa, 2007.

3 Garcia, José Manuel: As Filipinas na Historiografia Portuguesa do século XVI / Filipinas in Portuguese XVIth Century Historiography, Centro Português de Estudos do Sudeste Asiático, Lisboa, 2003, págs. 12-16. 
Nos anos 30 do século XVI, os portugueses estabelecidos nas Molucas contactaram com populações das Filipinas, sobretudo em Mindanau, tendo em vista propósitos económicos e de evangelização, mas não tendo encontrado aí especiarias ou metais preciosos não criaram qualquer entreposto nessa ilha, pois se tivessem descoberto esses bens logo ali teriam concentrado a sua atenção, como o vieram a fazer pouco tempo depois nas mais longínquas ilhas do Japão, onde souberam da existência de prata. ${ }^{4}$

Ainda na década de 30 do século XVI os portugueses sedeados em Malaca e outras localidades do Sudeste Asiático começaram pouco a pouco a retomar a realização de viagens à China, ainda que de forma clandestina, tendo sido no decorrer de uma dessas viagens que foram os primeiros europeus a estar na ilha de Luzon, no norte das Filipinas, como o atesta António Galvão ao escrever cerca de 1550:

"No ano de 1545, em mês de Junho, partiu um junco da cidade de Bornéu, em que ia um português que se chamava Pero Fidalgo; arribaram com tempo contrário ao Norte; acharam uma ilha de nove ou dez graus, até vinte e dous de altura, a que chamam dos Lucões, por assim haverem nome os habitadores dela, pode ter outros, e assim seus portos, que ainda agora não sabemos. Corre-se de Nordeste a Sudoeste; jaz entre Mindanao e a China. Diz que foram ao longo dela duzentas e cinquenta léguas, em que a terra era fresca e bem assombrada, e contam que dão ali dous pesos de ouro por um de prata, ainda que é mui vizinha da terra da China". ${ }^{5}$

Apesar da limitação destas indicações elas revelam os dados iniciais de uma observação directa de europeus relativamente a ilhas do Norte das Filipinas, as quais foram representadas num padrão cartográfico que de seguida foi copiado nos mapas portugueses da época. Um dos mapas contendo o registo dessas ilhas e das restantes terras que os portugueses conheciam em 1567 no Sudeste Asiático e Ásia Oriental foi mostrado neste ano aos espanhóis, que em 1565 haviam chegado às Filipinas com o objectivo de as ocupar. As informações fornecidas por aquele mapa foram muito úteis a esses espanhóis sob o comando de Miguel López de Legazpi, pois puderam assim começar a conhecer de uma forma mais ampla a região em que se encontravam. O português que foi responsável pela observação do

4 Ibidem, pág. 18-31.

5 Tratado dos Descobrimentos, edição de Visconde de Lagoa, Livraria Civilização Editora, Porto, 4. ${ }^{\text {a }}$ edição, 1987, pág. 169 (obra publicada pela primeira vez em 1563, sendo uma edição póstuma, pois o autor morreu em 1557). Sobre este assunto véase Garcia, José Manuel: As Filipinas na Historiografia... págs. 41-43. 
referido mapa foi um mensageiro de Gonçalo Pereira Marramaque, a quem alude de forma muito critica o cronista Diogo do Couto ao tratar das expedições dirigidas por aquele capitão-mor da armada portuguesa das Molucas, referindo que este, depois de ter provido:

\begin{abstract}
"em algumas cousas ordenou de tornar contra os castelhanos, pera o que se fez prestes; despediu diante um António Rombo, de sua obrigação, com duas coracoras pera ir a Cebu a visitar o Miguel Lopez de Lagaspa; e a voltas disso se inteirar do poder que tinha, e se lhe viera de Nova Espanha mais socorro e se tinha descoberto o caminho da volta pera lá; mas como este homem era (segundo diz Gabriel Rebelo que o tratou), tão rombo do engenho, como da alcunha, nem soube apalpar as cousas como convinha, nem perguntar com a dissimulação devida por algumas, antes em vez de aproveitar prejudicou, porque inconsideradamente mostrou aos pilotos castelhanos uma carta de marear que eles estimaram muito, porque por ela alcançaram o caminho da China e Japão e de todo aquele arquipélago, cousa que eles não sabiam e que compraram por muito, que tudo lhe o Rombo deu por tão pouco como foi o de sua ignorância". ${ }^{6}$
\end{abstract}

Gonçalo Pereira Marramaque estava nessa altura nas Molucas, vindo de Goa, e ao saber em Bornéu que os espanhóis estavam na ilha de Cebu decidiu que os deveria desalojar dessa posição, reagindo assim de uma forma idêntica à de outros dirigentes portugueses que haviam feito o mesmo relativamente a espanhóis que anteriormente tinham tentado estabelecer-se nas Molucas, com a intenção de proceder ao tráfico das especiarias. Para fundamentar a sua reacção o capitão português alegava que as Filipinas, tal como as Molucas, se encontravam na parte do mundo sob o domínio da coroa portuguesa, de acordo com o que havia sido estipulada nos tratados de Tordesilhas e de Saragoça assinados pelos reis de Portugal e Espanha respectivamente em 1494 e 1529 . Até 1565 os espanhóis, que também reivindicavam o direito às ilhas daquela parte da Ásia, não lograram estabelecer-se na região por causa da oposição dos portugueses e sobretudo porque não tinham descoberto a forma de fazer a viagem de regresso ao México, de onde podiam receber apoio e para onde podiam enviar produtos. $\mathrm{O}$ conhecimento da forma de fazer tal regresso só foi conseguido nesse ano de 1565 após o frade agostinho Andrés de Urdaneta ter voltado ao México por uma região do Pacífico que estava situada mais a norte.

6 Diogo do Couto e a década 8. $^{a}$ da Ásia (livro 4, cap. 1. ${ }^{\circ}$ ), edição de Maria Augusta Lima Cruz, Comissão Nacional para as Comemorações dos Descobrimentos Portugueses / Impressa Nacional-Casa da Moeda, Lisboa, 1993, v. 1, pág. 313. 
As acções militares que os portugueses levaram a cabo em 1568 para expulsar os espanhóis de Cebu não tiveram êxito e por isso estes puderam começar a dominar as Filipinas. ${ }^{7}$ Apesar da vitória alcançada pela resistência de Legazpi este preferiu evitar novas ameaças dos rivais peninsulares, que não o queriam deixar aproximar-se dos seus valiosos negócios do cravo nas Molucas, decidindo ir para norte, de onde seria mais fácil contactar com a China, pois sabia que neste território se podiam fazer negócios muito lucrativos. Os espanhóis foram então para a ilha de Luzon, instalando em Manila a sua principal base de apoio, tendo-lhe dado em 24 de Junho de 1571 o título de cidade e tendo então sido eleitos os seus alcaides e regedores. ${ }^{8}$

Quando Legazpi chegou às Filipinas havia já uma década que os portugueses se tinham estabelecido em Macau, que passou a ser um entreposto mercantil que prosperava devido à realização de actividades mercantis regulares com o Japão, por um lado, e Cantão, por outro. A normalização em 1557 das condições em que Macau desenvolvia o seu comércio permitiu que esta cidade se tornasse um dos principais portos da região, com vantagens recíprocas para portugueses e chineses.

$\mathrm{O}$ grande interesse que havia nestes tempos pela China reflectiu-se na edição do Tractado em que se contam muito por extenso as cousas da China (...) de Frei Gaspar da Cruz, obra que acabou de ser impressa em 20 de Fevereiro de 1570 em Évora por André de Burgos.

Há ainda a considerar que a fixação dos espanhóis em Manila ocorreu quando haviam passado cerca de duas décadas do início das navegações dos portugueses para o Japão, sendo por coincidência precisamente nesse ano de 1571 que estes fundaram uma cidade em Nagasaqui, a partir de uma pequena aldeia de pescadores, tal como o haviam feito em Macau. Esta informação foi registada em 8 de Outubro de 1571 pelo jesuíta Miguel Vaz em carta que então escreveu do Japão, na qual refere que: "Chegando-se o tempo veio a nau da China e um junco a um bom porto novo de Dom Bartolomeu, o qual se chama Nangasaqui. No qual porto se fez este ano uma grande povoação, por ser terra pera isso de cristãos". ${ }^{9}$ A partir desta data os portugueses consolidaram a muito lucrativa rota que até 1639 ligou regularmente Macau a Nagasaqui, suscitando a cobiça sucessivamente de espanhóis, holandeses e ingleses.

7 Garcia, José Manuel: As Filipinas na Historiografia..., págs. 43-60.

8 Boletim da Filmoteca Ultramarina Portuguesa, Lisboa, n. ${ }^{\circ}$ 32, 1966, pág. 18.

9 Cartas de Japão, apresentação de José Manuel Garcia, volume 1, Castoliva Editora, Maia,1997 (fac-simile da edição de 1598), f. 316v. 
Durante a primeira década em que os espanhóis estiveram em Manila foram escassos os contactos estabelecidos com os portugueses de Macau, sabendo-se apenas que em 1579 saíram das Filipinas os frades franciscanos Pedro de Alfarro e Giovanni Lucarelli para irem a Cantão, de onde foram expulsos e enviados para Macau, aí chegando em 15 de Novembro desse ano. Há ainda indicação que refere em 1580 a presença em Manila de dois navios vindos de Macau.

\section{Questões económicas colocadas pelo início do período filipino da história de Portugal}

Numa perspectiva oficial a ida de espanhóis a Macau iniciou-se após a subida em 1580 de Filipe II de Espanha ao trono de Portugal como Filipe I, tendo a notícia deste evento sido levada a essa cidade em 1582 pelo jesuíta espanhol Alonso Sánchez, que, na condição de embaixador do governador das Filipinas, dom Gonzalo Ronquillo, aí se deslocou para promover a aclamação do novo rei pelos portugueses.

Filipe I foi jurado em Macau como rei de Portugal e dom João de Almeida, seu capitão-mor na cidade, enviou a Manila uma carta datada de 24 de Junho de 1582 em que prestava obediência ao rei e expressava uma polida e optimista expectativa de que no futuro houvesse para as duas cidades um "continuo trato e comércio pelo muito proveito temporal e espiritual de que isto resultaria", ainda que ressalve com prudência: "mas agora parece-nos que será melhor dissimular este comércio até que tudo seja entendido por sua majestade dê a ordem que mais convenha ao seu serviço e assegure as coisas destas cidade, porque como digo, se receiam muito de ver chegar aqui espanhóis dessas ilhas". ${ }^{10}$

Alonso Sánchez aproveitou a ida a Macau para se deslocar a Cantão, onde em vão diligenciou junto das autoridades locais para tentar obter autorização para que os espanhóis pudessem estabelecer relações mercantis com a China. No regresso às Filipinas o jesuíta sofreu um naufrágio em Taiwan, tendo ido depois para Manila a bordo de um junco de Bartolomeu Vaz de Landeiro, magnate português da região, que em 27 de Março de 1583 levou para aquela cidade vinho e azeite, tecidos indianos, e sobretudo sedas e outros produtos chineses, cuja venda a troco fundamentalmente de prata beneficiou largamente portugueses e espanhóis. Estes chegaram

10 Teixeira, Manuel: Macau e a sua diocese, volume 1, Macau, 1940, págs. 136-139. 
mesmo a alimentar a expectativa de um período de mútuos benefícios mercantis para Macau e Manila, pois aquele português foi então autorizado a fazer uma viagem anual entre as duas cidades. ${ }^{11}$

Os galeões de Manila traziam anualmente prata do México e do Peru que tinha grande procura na China, sendo o seu valor maior aí do que na Europa, motivo pelo qual a prata começou a ser levada para Macau, juntamente com produtos das Filipinas em que se destacavam o arroz, o açúcar, cera, cordame, conchas para persianas e frutas tropicais, fornecendo os portugueses sedas e porcelanas, a que se juntavam bens como por exemplo cobre, jades, tecidos indianos, armas e munições.

Nos séculos XVI e XVII uma travessia de Macau a Manila levava quinze a vinte dias e em geral não oferecia dificuldades náuticas, tendo pilotos portugueses escrito roteiros manuscritos que forneciam as indicações necessárias para a realização das navegações não apenas entre Macau e Manila, mas entre estas cidades e outras partes da Ásia Oriental e do Sudeste Asiático.

O desejo de obter lucros elevados com o comércio em Macau levou a que os tripulantes do galeão espanhol San Martín, que em Junho de 1583 largou de Manila para Acapulco, se revoltassem contra o seu capitão, Francisco de Mercado, tendo ido a Macau para carregar seda e outros produtos chineses, antes de seguirem viagem para a América. Esse navio ainda estava em Macau quando em Março de 1584 Bartolomeu Vaz Landeiro com dois juncos foi a Manila, informando o governador das Filipinas da situação do navio espanhol revoltado. O governador Diego Ronquillo enviou logo um navio a Macau com o feitor da Fazenda Real, Juan Bautista Román, e o jesuíta Alonso Sánchez, chegando a esta cidade em 1 de Maio, onde prenderam e condenaram os culpados do motim. $\mathrm{O}$ galeão recebeu de seguida uma nova tripulação e partiu para Acapulco. ${ }^{12}$

Em 1583, ainda que apenas confirmado pelo vice-rei do Estado da Índia em 10 de Abril de 1586, foi criado em Macau um senado, instituição superior de administração local que reforçava o poder e a autonomia da oligarquia mercantil dos portugueses que ali centravam os seus negócios, contribuindo também para uma melhor organização da cidade, tendo em atenção, nomeadamente, os interesses expansionistas dos espanhóis fixados em Manila.

11 Videira Pires, Benjamim: A viagem de comércio Macau-Manila nos séculos XVI a XIX, Centro de Estudos Marítimos de Macau, Macau, 1987, 2. ${ }^{\text {a }}$ edição, pág. 8-9.

12 Ibidem, pág. 9. 


\section{Rivalidades económicas luso-espanholas na Ásia Oriental em finais do século XVI}

Contrariando o panorama sem adversidades da primeira metade da década de 80 do século XVI a ancestral rivalidade luso-espanhola voltou a reafirmar-se pouco a pouco, levando à necessidade de separar os diferentes interesses de portugueses e espanhóis na área, numa disposição que tinha sido reconhecida oficialmente por Filipe I de Portugal e II de Espanha nas cortes realizadas em Tomar em 1581. Por tal motivo o rei lembrava em carta de 21 de Janeiro de 1587 ao vice-rei do Estado da Índia dom Duarte de Meneses que:

\footnotetext{
"na armada que o ano de 1585 foi para essas partes vos mandei escrever que não havia por meu serviço terem os castelhanos comércio nenhum nas partes da China e Maluco, nem os portugueses nas Filipinas, como entendeis que convém, senão somente boa correspondência uns com os outros; e assim o mandei escrever ao visorei daquelas partes que o havia por meu serviço, vos torno a encomendar o façais assim guardar inteiramente. ${ }^{13}$
}

Quem não se revelou preocupado com o serviço do rei foram os comerciantes locais que frequentemente desobedeceram à legislação que impedia a realização de comércio de espanhóis com a China por um lado e de portugueses com as Filipinas e o México por outro, pelo que as trocas entre Macau e Manila foram quase sempre consideradas clandestinas, além de muitas vezes serem realizadas através de chineses ou por navios de outras proveniências.

Já em 1 de Abril de 1585 o jesuíta Alessandro Valignano informava de Goa que "agora o vice-rei envia grandes protestos ao governador das Filipinas e grandes provisões à cidade de Macau, que vendo aí castelhanos sem ordem particular de sua majestade os enviem presos para a Índia". ${ }^{14}$

A maioria dos comerciantes de Macau defendeu intransigentemente até aos inícios do século XVII a proibição da ida de espanhóis à China, ainda que não tivesse negado a possibilidade unilateral de levar navios a Manila, pois só assim os seus interesses não seriam asfixiados pelos negócios dos espanhóis. Uma das suas principais alegações era a de que a seda

13 Arquivo português oriental, Imprensa Nacional, Nova Goa, 1861, fascículo 3, parte 1, págs. 80-81.

14 Documenta Indica, volume XIV, Instituto Historicum Societati Iesu, Roma, 1979, págs. 8-9. 
chinesa seria então insuficiente para abastecer todos os mercados que a queriam, sendo outra a de que os espanhóis desequilibravam as relações dos portugueses com os chineses e faziam aumentar os preços da seda, como o explicou cerca de 1599 Diogo do Couto ao escrever sobre as ordens que Filipe I de Portugal mandava em 1585, nas quais:

\begin{abstract}
"sob graves penas defendia que nenhum castelhano fosse aos portos da China pelo grande prejuízo que nisso recebia o Estado da Índia todo, porque com muito dinheiro que metiam em suas feiras por comprarem tudo, alteravam os preços em excessivo modo, e os mercadores todos da Índia ficavam perdendo nisso tanto, que onde se ganhava cinquenta e sessenta por cento, veio a menos de vinte e cinco. El-rei perdia em suas alfândegas muita cópia de dinheiro, porque toda a seda, e fazendas que os castelhanos levavam, lhe faltavam. Esta provisão entregou o viso-rei a Domingos Monteiro, que ia fazer a viagem de Japão que comprou, pera que a mandasse (a)pregoar em Malaca e China". ${ }^{15}$
\end{abstract}

Em resposta às ordens dadas ao vice-rei dom Duarte de Meneses, este enviou ao rei uma carta em 23 de Novembro de 1587 na qual declarava a impossibilidade de fazer cumprir na Índia as provisões impeditivas de irem castelhanos à China e portugueses às Filipinas, caso não mandasse ordens enérgicas para que elas fossem respeitadas pelos seus súbditos, ${ }^{16}$ queixando-se depois numa carta de 15 de Abril de 1588 que uma nau espanhola carregada de prata aportara a Macau, o que considerava muito prejudicial. ${ }^{17}$

Manuel de Sousa Coutinho, o sucessor de dom Duarte de Meneses, por carta enviada ao rei em 10 de Dezembro de 1588 insistia de novo nos grandes inconvenientes das viagens comerciais dos espanhóis do México para a China. ${ }^{18}$

Não foram apenas os portugueses de Macau e da Índia que se esforçavam por evitar os contactos directos dos espanhóis com a China, mas sobretudo os espanhóis de Sevilha, que verificaram que tais contactos estimulavam a drenagem de prata americana para a China em detrimento dos seus interesses, realidade que se agravou sobretudo a partir de inícios do século XVII, quando começaram a ver diminuídos consideravelmente os ingressos de prata americana na Espanha.

15 Da Ásia de Diogo do Couto. Dos feitos, que os portugueses fizeram na conquista, e descobrimento da terras, e mares do Oriente, década X (parte segunda, livro VI, capítulo V), Régia Oficina Tipográfica, Lisboa, 1788, págs. 38-39.

16 Boletim da Filmoteca Ultramarina Portuguesa, n. ${ }^{\circ}$ 15, 1960, pág. 535.

17 Ibidem, pág. 557-558 e 581.

18 Ibidem, pág. 550. 
Posições contrárias a medidas proibitivas em vigor foram expressas em 1588 por alguns portugueses como o bispo de Malaca. dom João Ribeiro Gaio, nomeadamente numa carta de 31 de Dezembro desse ano em que defendeu as vantagens em ser levantada a interdição de comércio entre os portugueses da China e os castelhanos da Nova Espanha, apontando o modo como este deveria ser efectuado. ${ }^{19}$

Foi no contexto da realização de negócios muito proveitosos nos anos 80 do século XVI do eixo Macau-Manila-México que foi levado a cabo por dom João da Gama um dos empreendimentos mais surpreendentes deste tempo. Com efeito este neto de Vasco da Gama realizou em 1589-1590 a única viagem de um navio português que atravessou o Pacífico nos séculos XVI a XVIII, indo de Macau e Acapulco, à imitação do que fizera em 1584 o galeão espanhol San Martín. ${ }^{20}$

Dom João da Gama fôra capitão de Malaca entre 1579 e 1582, onde aclamou Filipe I em 23 de Novembro de 1581, tendo feito em 1588 "uma viagem da China", estando então muito bem visto em Macau, como se pode ver pela carta que a câmara de Macau escreveu ao rei a 30 de Junho de 1588, na qual se louva Gama, então capitão de Macau e Japão. Aí se pedia ainda ao rei que lhe fosse concedida vitaliciamente esta capitania, além de lhe referir o prejuízo das viagens da Nova Espanha para Macau e os motivos por que deviam ser proibidas, salientando o perigo dos navios espanhóis serem apresados pelos ingleses, aproveitando a ocasião para pedir autorização para os moradores de Macau irem com suas fazendas à Nova Espanha com a desculpa de que com o produto da viagem poderiam sustentar igrejas, a misericórdia e dois hospitais, sendo um de leprosos. ${ }^{21} \mathrm{~A}$ posição favorável ao mencionado fidalgo aqui manifestada viria ser depois alterada quando se verificou que este armou uma grande nau de 600 toneladas que em vez de ir de Macau para a Índia foi para o México, onde se poderiam realizar negócios muito mais lucrativos, os quais eram cobiçados pelos moradores de Macau, como acabámos de ver.

A decisão de dom João da Gama foi tomada com o conhecimento prévio da sua ilegalidade, pois era bem sabida a proibição do comércio entre

19 Ibidem, pág. 556.

20 Sobre este caso véase Boxer, Charles R.: Fidalgos no Extremo Oriente, 1550-1770: factos e lendas de Macau antigo, Fundação Oriente, Macau, 1990, pág. 57; ibidem, O grande navio de Amacau, Fundação Oriente / Museu e Centro de Estudos Marítimos, Macau, 1989, pág. 46 e Bryan Souza, George: A sobrevivência do império: os portugueses na China (1630-1754), Publicações D. Quixote, Lisboa, 1991, pág. 89.

21 Boletim da Filmoteca Ultramarina Portuguesa, n. ${ }^{\circ}$ 15, 1960, pág. 580. 
os domínios de Portugal e Espanha. A decisão insólita e excepcional de fazer tal viagem poder-se-ia prender por um lado à expectativa de que a iniciativa talvez fosse olhada com tolerância, tal como acontecera em viagens precedentes de espanhóis, mas por outro lado, admitimos que tivesse sido tomada em posição de desespero de Gama, pois este teria entretanto sabido que se regressasse a Goa seria preso devido à acusação de ter cometido graves irregularidades. Esta realidade está patente na carta que o rei enviou para o vice-rei em 6 de Fevereiro de 1589, na qual lhe ordenava que quando aquele fidalgo chegasse da "China o façais prender em ferros, e que com eles, sem se lhe tirarem na viagem, seja embarcado pera este reino nas naus desta armada", como já o ordenara em 1587, revelando uma grande irritação face aos crimes por ele cometidos. ${ }^{22} \mathrm{O}$ fidalgo em causa, contudo, parecia alheado desta realidade em 1588 pois enviou de Macau a 20 de Novembro uma carta ao rei em que o informava da sua intenção de ir a Espanha por via do México com uma alegada justificação de lhe ir pessoalmente dar parte da sua missão à China e mostrar quão fácil lhe parecia empreender-se a sua conquista. ${ }^{23}$ Dois dias antes, em 18 de Novembro, Domingos Segurado escrevia igualmente de Macau ao rei para o informar do naufrágio duma nau da Nova Espanha em Macau e do embarque da sua tripulação no navio de dom João da Gama, proprietário de uma viagem ao Japão, que, uma vez em Macau, aceitara a ordem do vice-rei para transportar a dita tripulação e que em sua substituição ele ficava no ofício de capitão de Macau, durante a sua ausência, sugerindo ainda a sua nomeação para esse cargo, ou, em recompensa de seus serviços, a concessão de duas viagens da China para a Nova Espanha. ${ }^{24}$

O navio de Gama depois de iniciar a viagem no Pacífico foi obrigado por uma tempestade a aportar ao Japão onde fez reparações tendo retomado a sua rota em Outubro de 1589, descortinando de seguida uma "Terra de Gama", que talvez corresponda a uma das ilhas Curilhas. Ao chegar a Acapulco em Março de 1590, as autoridades locais fizeram cumprir a legislação real e prenderam o infractor, sequestrando-lhe os bens, que foram avaliados em 140000 pesos. O processo de dom João da Gama seguiu para a Casa de la Contratación em Sevilha, onde se veio a arrastar. Os restantes mercadores que haviam participado na viagem regressaram a Macau via Filipinas, após uma estadia no México, de onde trouxeram prata.

22 Arquivo português oriental, fascículo 3, parte 1, 1861, pág. 169.

23 Boletim da Filmoteca Ultramarina Portuguesa, n. ${ }^{\circ}$ 15, 1960, pág. 554.

24 Ibidem, pág. 578. 
Admitindo-se que dom João do Gama tenha sido enviado para Sevilha terá sido o primeiro homem conhecido a completar uma volta ao mundo em sentido contrário ao da viagem dos sobreviventes da armada de Fernão de Magalhães, pois tendo ido para Macau pela rota do cabo da Boa Esperança fez a viagem de regresso à Europa por uma via que continuou em direcção ao oriente seguindo as rotas espanholas.

A atitude de Gama foi condenada pela câmara de Macau como o revelam as queixas expressas contra ele na carta do governador Francisco de Sousa Coutinho de 3 de Abril de 1589, pois foi aí acusado de ter vendido a viagem ao Japão a que tinha direito e de ter mandado uma nau sua à Nova Espanha, carregada de fazendas que eram destinadas à Índia. Perante esta situação o governador enviou o licenciado Rui Machado para pôr termo a estas ilegalidades e fazer embarcar para a Índia todos os castelhanos que encontrasse em Macau, denunciando mais uma vez os prejuízos causados pela navegação castelhana à China. ${ }^{25}$ Os portugueses continuaram então a manifestar-se abertamente contra a presença de espanhóis em Macau, como o revela o embargo que fizeram a um navio espanhol que em 1590 ali foi. ${ }^{26}$

Como se verifica pela resposta que Filipe I de Portugal enviou a Matias de Albuquerque em 12 de Janeiro de $1591,{ }^{27}$ a carta atrás citada chegara a Portugal, pois refere nela que o governador "pelas desordens que D. João da Gama cometeu na China mandara àquelas partes o licenciado Rui Machado (...) e que antre as cousas que levara por regimento fora que todos os castelhanos seculares e eclesiásticos que achasse naquela cidade fizesse embarcar para essas partes ou pera os Luções, de maneira que não ficassem em Macau senão os portugueses moradores antigos, por se atalhar o prejuízo que nisto recebiam meus vassalos portugueses".

$\mathrm{Na}$ conjuntura aqui considerada é de assinalar que em 23 de Maio de 1590 os vizinhos de Manila fizeram uma petição no sentido de serem autorizados a fazer negócios com os mercadores de Macau, ${ }^{28}$ continuando a revelar nos anos seguintes interesse em fazer comércio com a China, apesar das proibições de relacionamento luso-espanhol continuarem em vigor, mesmo que não fossem cumpridas. Tal facto verifica-se através da sucessão de ordens que foram sendo repetidas, nomeadamente nas que em 1 de

25 Ibidem, pág. 586.

26 Videira Pires, Benjamim: A viagem de comércio..., pág. 12.

27 Arquivo português oriental, fascículo 3, parte 1, 1861, pág. 276.

28 Boletim da Filmoteca Ultramarina Portuguesa, n. ${ }^{\circ}$ 26, 1964, pág. 127. 
Março de 1594 foram enviadas ao vice-rei do Estado da India Matias de Albuquerque, nas quais se mandava que fosse evitado o comércio entre navios espanhóis e aquele Estado; não restituísse o dinheiro embargado a dom Rodrigo de Córdova, capitão espanhol que aportara a Macau para comprar mercadorias na China por conta de comerciantes espanhóis, e se proibisse o comércio entre as Índias Ocidentais e Orientais. ${ }^{29}$ No sentido de reforçar tal atitude o rei enviou mais um alvará em 9 de Março de 1594 no qual confirmava a ordem anterior para "que de todo cesse este comércio e que não haja de nenhuma das partes que estão sob o governo e administração dos castelhanos para as dos portugueses nem de uma a outros", além de que interditava o transporte de religiosos castelhanos para Macau e Malaca, a não ser que tivessem uma licença do rei passada pelos ministros da coroa de Portugal. ${ }^{30} \mathrm{~A}$ mesma proibição mercantil surge numa carta régia de 7 de Março de $1596 .{ }^{31} \mathrm{~A}$ insistência destas medidas é reveladora da sua ineficácia.

A falta de cumprimento das determinações régias está bem patente em 1598, ano em que o rei enviou em 18 de Fevereiro mais uma carta na qual mandava o vice-rei do Estado da Índia, dom Francisco da Gama, conde da Vidigueira, cumprir a provisão que proibia o comércio entre as Filipinas, a Nova Espanha e a China, ${ }^{32}$ reforçando tal posição com o envio em 12 de Março de mais um alvará proibindo a navegação do Estado da Índia para as Filipinas ${ }^{33}$ e outro de 19 de Março ordenando que todos os anos fosse tirada uma devassa às pessoas acusadas de fazer comércio com as Filipinas, havendo particular cuidado em averiguar se os capitães de Malaca incorriam nessa culpa. Todos os que fossem dados por culpados deveriam ser severamente castigados. ${ }^{34}$ Ora nesse mesmo ano de 1598 as infracções às ordens do rei por parte dos espanhóis deram origem a um acto que se revestiu de maior gravidade, o qual consistiu na realização de comércio na China pelo capitão dom Juan Zamudio, ${ }^{35}$ que para lá foi numa fragata enviada

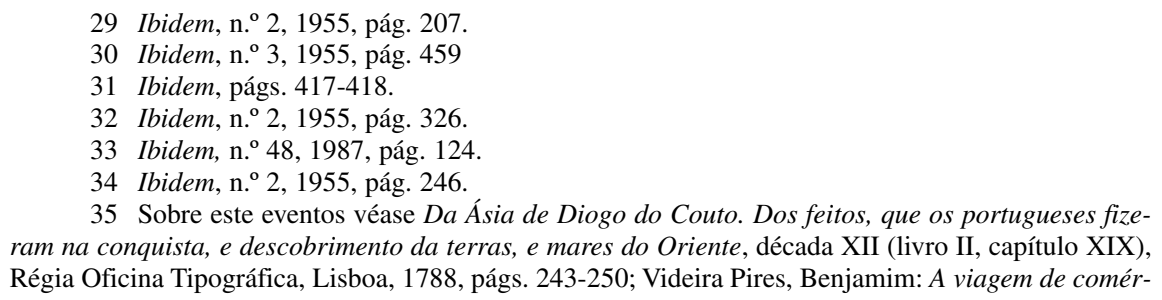

35 Sobre este eventos véase Da Ásia de Diogo do Couto. Dos feitos, que os portugueses fizeram na conquista, e descobrimento da terras, e mares do Oriente, década XII (livro II, capítulo XIX), Régia Oficina Tipográfica, Lisboa, 1788, págs. 243-250; Videira Pires, Benjamim: A viagem de comércio..., págs. 12-14. 
pelo próprio governador das Filipinas, sob a alegação que os dois reinos tinham o mesmo rei. Este navio foi a Cantão e mediante o pagamento de grandes quantias os espanhóis forram autorizados pelos chineses a fazer comércio no porto chamado do Pinhal, mas com a condição de não desembarcarem e não voltarem lá, como afirmaram as autoridades locais numa tradução portuguesa coeva: "Isto se entenderá por este ano somente e daqui em diante não tornem cá mais". Jin Guo Ping e Wu Zhiliang referem que em Guangdong Tongzhi (Crónica Geral de Guangdong) da autoria de Jin Guangzhu:

"No $5^{\circ}$ dia da $8^{\text {a }}$ lua do $26^{\circ}$ ano (24 de Julho de 1598$)$ do Reinado de Wanli (15731615), gentes de Lução vieram de repente para ancorarem em Haojing'ao (Baía de Vieira, Macau), solicitando a apresentação de tributos. O governador de Guangdong considerando ilegal a sua entrada, decidiu expulsá-las. Os portugueses de Macau reforçaram também a sua defesa, impedindo o desembarque dos luções. Na $9^{\text {a }}$ lua (Setembro), transferiram-se para Hutiaomen (Porta de Saltos de Tigre), dizendo à espera que os seus barcos fossem medidos. Na 10 lua (Setembro-Outubro), mandaram dizer que tinham chegado a Jiazimen (Porta do Ciclo Sexsagesimal). Avariados os barcos, ficaram a residir em Hutiaomen, sem intenção de se retirar. O Haidao Zhang Banghan enviou para lá tropas, tendo queimado a sua povoação. $\mathrm{Na} 9^{\mathrm{a}}$ lua (Julho-Agosto) do ano seguinte (1599), é que regressaram para o mar leste. Há quem diga que vieram aliciados pelos comerciantes de Guangdong e Fujian”.

Segundo Jin Guo Ping e Wu Zhiliang o local chamado de Pinhal situase numa das desembocaduras do Xijiang (Rio de Oeste), situada a cerca de 12 milhas de Macau.

Os portugueses sob o comando de dom Paulo de Portugal fizeram nessa altura múltiplas diligências junto das autoridades chinesas e dos espanhóis para que estes abandonassem aquele local, o que só fizeram em 1599, depois da ocorrência de um confronto em Macau.

\section{Testemunhos de viajantes sobre relações luso-espanholas nos finais do século XVI na Ásia Oriental}

Para lá dos dados que até aqui sumariámos o ambiente que marcou a história das relações entre Macau e as Filipinas nos finais do século XVI pode ser ainda ilustrado com dados fornecidos por viajantes que nos deixaram os seus testemunhos escritos sobre as experiências que viveram nesta parte do mundo. De entre os casos conhecidos começamos por apontar as 
observações feitas por Francesco Carletti, ${ }^{36}$ que estando em 1596 no México decidiu ir com o pai às Filipinas pela rota de Acapulco. Ambos partiram desta cidade em 25 de Março de 1596 e depois de terem atravessado o Pacífico em sessenta e seis dias chegaram às Filipinas, tendo permanecido algum tempo em Manila. Quando os dois florentinos mostraram ao governador espanhol a vontade de ir a Macau este afirmou peremptoriamente que não podia passar licenças autorizando-os a ir a essa cidade, devido às proibições que nesse sentido recebera do rei de Espanha, pois quem fosse das Filipinas para a China perderia os bens, sendo aí preso e enviado para Lisboa. De forma a conseguir realizar o seu desejo Carletti e o pai tiveram de recorrer ao estratagema de deixar clandestinamente Manila em Maio de 1597 num navio japonês que ia para Nagasaqui, onde ficaram até 3 de Marco de 1598. Nesta última data os florentinos partiram para Macau realizando a viagem em doze dias num navio cujo capitão era filho de pai português e mãe japonesa, tendo a companhia de vários portugueses. Chegados a Macau os dois homens desembarcaram clandestinamente com os jesuítas que seguiam na embarcação, a quem pediram que lhes guardassem os seus bens, pois receavam que os portugueses lhos tirassem. Com efeito, no dia seguinte, Carletti e o pai foram presos e interrogados durante três dias pelos portugueses, pois tinham sabido que haviam estado nas Filipinas e eram ciosos em manter a proibição de comércio entre portugueses e espanhóis. Os florentinos acabaram por ser libertados mediante o pagamento de uma caução e a condição de irem para a Índia no próximo navio que para lá se dirigisse. Durante a estadia de Carletti em Macau o seu pai faleceu, sendo só depois do seu enterro que por via de Malaca e Goa seguiu numa conturbada viagem para a Europa, onde em 1602 concluiu a sua volta ao Mundo.

Pedro Teixeira foi outro dos contemporâneos de Carletti que deu uma volta ao mundo passando por Manila. ${ }^{37}$ Este homem de negócios português fôra para o Índico pela rota do cabo da Boa Esperança em data incerta, ten-

36 Sobre as viagens desta personalidade consultámos a obra que escreveu nas edições Razonamientos de mi viaje alrededor del mundo 1594-1606, estudo preliminar, tradução e notas de Francisca Perujo, Universidade Nacional Autónoma de México / Instituto de Investigaciones Bibliográficas, México, 1976 e Voyage autour du monde de Francesco Carletti, 1594-1606, introdução e notas de Paolo Carile, tradução de Frédérique Verrier, Chandeigne, Paris, 1999.

37 Sobre as viagens desta personalidade consultámos a obra que publicou em 1610 na edição de Barajas Salas, Eduardo: Relaciones de Pedro Teixeira: del origen, descendencia y sucession de los reyes de Persia, y de Harmuz y de un viage hecho por el autor desde la India Oriental hasta Italia por tierra, Miraguano Ediciones / Ediciones Polifemo, Madrid, 1994. 
do decidido regressar a Portugal pela rota de Acapulco "para encurtar caminho e ver mundo". Em 1 de Maio de 1600, Pedro Teixeira deixou Malaca, onde se encontrava, rumo às Filipinas, tendo em 22 de Junho chegado à "baía de Cavite, porto da ilha e cidade de Manila, cabeça e governo das ilhas de Luçon, que assim as chamam os naturais, e são as que nós dizemos Filipinas". Pedro Teixeira aproveitou a sua viagem para levar ao governador de Manila informações do capitão de Malaca, Martim Afonso de Melo, nas quais o advertia da entrada naquele mar de navios holandeses. Talvez tenha sido o facto de levar tais informações que permite explicar a concessão das facilidades que lhe foram acordadas pelos espanhóis no embarque em uma das naus que ia para Acapulco, pois como o nosso viajante reconheceu a sua partida para essa cidade mexicana foi autorizada por uma licença que o governador só dava "com muita dificuldade" e "por grande favor" do capitão do navio que partiu de Manila em 18 de Julho de 1600, o qual tinha uma carga avaliada em 400000 ducados e levava poucas armas. Em 1 de Dezembro de 1600, Pedro Teixeira chegou a Acapulco, indo depois para Havana, de onde saiu em 15 de Julho de 1601 para entrar em Sevilha em 8 de Setembro desse ano, concluindo em Lisboa a 8 de Outubro a sua volta ao mundo.

\section{A intervenção holandesa no Oriente e a melhoria das relações luso-espanholas em inícios do século XVII em Macau e nas Filipinas}

A presença dos holandeses no Sudeste Asiático e na Ásia Oriental, que Pedro Teixeira assinalou no seu testemunho, constituiu desde os finais do século XVI um perigo para a navegação e as possessões de portugueses e espanhóis nessa parte da Terra, os quais se passaram a debater com um poderoso rival que alterou significativamente o panorama mercantil da região. Esta realidade contribuiu para a necessidade de atenuar a hostilidade luso-espanhola que até aí se manifestara de forma mais ou menos notória, com algumas excepções, nomeadamente no apoio dado pelos espanhóis aos portugueses das Molucas na década de 80 do século XVI, ainda que acabassem por não lograr resultados positivos.

Depois de em 27 de Outubro de 1601 ter ocorrido um primeiro incidente com os holandeses em Macau, sem consequências para os portugueses, é particularmente significativo que em 30 de Julho de 1603 uma nova 
expedição holandesa tenha voltado à cidade e tomado num assalto de surpresa e sem resistência a nau que estava pronta para partir para o Japão com 1400 picos de seda.

Foi neste contexto que se começaram a realizar de novo viagens de navios de Macau a Manila, estando registados nas duas primeiras décadas do século XVII as seguintes presenças de navios: em 1602, um; em 1604, cinco; em 1605, dois; em 1606, um; em 1609, um; em 1610, um; em 1612, sete; em 1619, dez; em 1620, cinco e em 1621, dois. Esta realidade levou a que em 1623 os comerciantes portugueses que faziam as viagens entre Macau a Manila defendessem abertamente junto do vice-rei a necessidade de legalizar um comércio que era visto como vantajoso para as duas cidades, apesar de se saber ser realizado de forma clandestina mas em geral era tolerada. A defesa da legalização do comércio passava fundamentalmente pela alegação de que este deixara de prejudicar a coroa, pois já não havia escassez de seda chinesa para abastecer os mercados, ainda que o facto principal a levar os portugueses de Macau a alterar as suas anteriores posições de fecho de relações face aos espanhóis resultasse fundamentalmente dos danos que sofriam com os ataques dos holandeses aos seus navios, sobretudo quando tentavam passar para o Índico. Por outro lado a argumentação em defesa dos interesses dos habitantes de Macau passava ainda pela desculpa de que se fossem os portugueses a fazer o comércio entre a China e Manila haveria menos perigo dos produtos serem tomados pelos holandeses do que se fossem levados por navios chineses, como acontecia geralmente, pois estes eram mais facilmente roubados..$^{38}$

De entre os bens que os portugueses forneciam aos espanhóis contava-se, além da seda, o mercúrio necessário à refinação da prata americana, tendo por isso estabelecido um contrato que vigorou entre 1609 e $1615 \mathrm{em}$ que o forneciam pelo preço de cerca de 50 pesos por quintal, alcançando o lucro médio de 7 pesos por quintal.

A influência portuguesa em Manila nas primeiras décadas do século XVII reflectiu-se na criação em 1606 de uma misericórdia local, sendo um caso único no império espanhol. Tal instituição seguia o exemplo de Macau, cuja misericórdia havia sido fundada em 1569, de acordo com o modelo da de Lisboa, tal como aconteceu com as restantes misericórdias que os portugueses criaram entre Goa a Nagasaqui.

38 Videira Pires, Benjamim: A viagem de comércio ... pág. 20. 
Os ataques dos holandeses a interesses portugueses de Macau e espanhóis de Manila levou Filipe II de Portugal a ordenar a cooperação dos habitantes de ambas as cidades no combate a esses "rebeldes" protestantes, embora não tivesse deixado de insistir que o comércio entre Macau e a América espanhola continuava proibido, o que fez nomeadamente em 25 de Fevereiro e 19 de Março de 1609.

Em 2 de Abril de 1613, o vice-rei do Estado da Índia dom Jerónimo de Azevedo, voltava também a proibir a ida de castelhanos à China, na sequência do rei "ter mandado a estas partes muitas provisões e instruções que com graves penas cesse o dito comércio e que cada ano se tire devassa daqueles que cometem aquela viagem." ${ }^{39}$ O mesmo vice-rei em carta não datada acabou por reconhecer que a proibição régia da comunicação entre a China e as Filipinas não era possível enquanto não se fechasse o caminho para Manila e que o grande prejuízo do Estado da Índia não tinha origem no comércio entre a China e as Filipinas, mas sim no comércio da seda destas ilhas com o México e o Japão. Este governante acabou até por defender a ideia de que a única maneira de resolver o assunto seria a de se proibir o comércio entre as Filipinas e o México, ordenando-se que a navegação para aquelas ilhas fosse feita apenas pelo cabo da Boa Esperança, comunicando assim Manila com o Estado da Índia, o que poderia contribuir para expulsar os holandeses dos mares do Sul. É curioso observar que um posição algo idêntica era partilhada por autoridades de Sevilha, pois em 1610 pressionavam Filipe III de Espanha contra interesses de espanhóis do México, levando a que o rei enviasse uma carta em 1 de Dezembro desse ano ao marquês de Castelo Rodrigo colocando-lhe a hipótese da viagem para as Filipinas passar a ser feita pela rota do cabo da Boa Esperança, ainda que tal atitude não tivesse em conta os interesse do Estado da Índia. ${ }^{40}$

O único caso conhecido da realização de uma viagem entre a Península Ibérica e as Filipinas pela rota do cabo da Boa Esperança poderá estar relacionada com estas ideias e foi a efectuada por uma armada de seis caravelas comandada pelo português Rui Gonçalves de Sequeira, a qual partiu em Fevereiro de 1614, tendo quatro dessas caravelas chegado a Manila em Agosto desse ano, enquanto uma foi para ao Brasil e outra a Angola. ${ }^{41}$

39 Arquivo português oriental, fascículo 6, 1875, págs. 942-943.

40 Veríssimo, Nelson : " $O$ tratado de Tordesilhas na união ibérica: a rota do Cabo e o comércio das Filipinas”, Islenha, 15, Funchal, 1994, págs. 5-14.

41 Sobre este assunto ver Bocarro, António: Década 13 da História da Índia, edição de Rodrigo José de Lima Felner, parte 1, Academia Real das Ciências, Lisboa, 1876, págs. 291-293. 
A continuação da existência de uma certa tensão entre portugueses e espanhóis neste período, apesar de medidas de cooperação, foi expressa pelos holandeses como o referiu o próprio Filipe II de Portugal na carta que em 22 de Setembro de 1613 quando escreveu ao vice-rei D. Jerónimo de Azevedo comunicando-lhe que os holandeses tinham confiança em expulsar os espanhóis das Filipinas, contando que para tal "os ajudaria a pouca conformidade que há entre castelhanos e portugueses". ${ }^{42}$

A rivalidade entre portugueses e espanhóis no Oriente, foi vivida num ambiente marcado por liberdade de iniciativas que era caracterizada pela expressão de uma grande "soltura", como era revelado pelo facto de que "tinham assentado fazer naquele ano viagem dali para Manila contra as proibições e defesas de vossa majestade" e até em certos momentos pela agressão a autoridades judiciais quando em Macau tentaram cumprir as ordens para impedir o comércio com as Filipinas e julgar os infractores, como relatou Fernão de Albuquerque baseado em informações de Lopo Sarmento registadas na carta que escreveu ao rei em 10 de Fevereiro de 1622.43

Em 1 de Março de 1614, o rei voltou a ordenar para a Índia que "cesse de todo" o comércio entre as Filipinas e Macau ${ }^{44}$ e em 3 de Abril de 1620, o governador do Estado da Índia Fernão de Albuquerque, escreveu ao governador das Filipinas referindo-lhe que seriam tomadas medidas rigorosas contra o comércio que os mercadores de Manila faziam com a China e o Japão, de acordo com as determinações régias que expressamente proibiam esse comércio. ${ }^{45}$ Pouco depois, em 2 de Maio de 1620, o mesmo governador escreveu ao ouvidor de Macau sobre a prisão e embargo das embarcações e depósito de dinheiro dos castelhanos, censurando-o por ter permitido que se voltasse a entregar tudo aos ditos castelhanos, o que era contrário às provisões régias que proibiam tanto a estes que comerciassem em Macau, como aos portugueses que o fizessem em Manila, devendo ele ter obrigação de velar pela execução dessas determinações. O governador censurava-o ainda por não ter votado na resolução que a cidade tomara ao entregar aos ditos castelhanos o que lhes fora embargado, coisa que devia ter impedido, concordando apenas com a entrega da prata vinda de Manila

42 Documentos remetidos da India ou livro das monções, Academia Real das Ciências, Lisboa, 1884, volume I, pág. 449.

43 Ibidem, volume VII, 1975, págs. 434-436.

44 Ibidem, volume II, 1884,1885, págs. 98-99.

45 Boletim da Filmoteca Ultramarina Portuguesa, 1959, volume 11, pág. 134. 
aos japoneses, para assim se evitarem as suas represálias. Recomendavalhe por fim que procedesse a uma devassa de todos os comerciantes portugueses que tivessem ido a Manila, ou que lá tivessem mandado navios, e dos que auxiliavam os castelhanos a fazerem comércio em Macau. ${ }^{46}$

$\mathrm{O}$ ano de 1620 ficou marcado por uma aliança entre a Holanda e a Inglaterra contra Portugal e a Espanha, que por vezes cooperavam entre si, de que é exemplo a ida em 1621 de Diogo Vaz Bávaro a Manila num pataxo, tendo então adquirido entre outros bens para Macau seis peças de artilharia, pagando por cada uma 2000 patacas. ${ }^{47}$ Este armamento e um pequeno destacamento espanhol das Filipinas que então veio para Macau contribuíram para o sucesso da sua defesa em 24 de Junho de 1622, quando foi atacada por uma poderosa força holandesa. ${ }^{48} \mathrm{O}$ referido fornecimento de armas terá sido excepcional, pois em geral foi de Macau que seguiam para Manila peças de artilharia e munições. Segundo o testemunho de Lourenço de Liz Velho o comércio com Manila realizado em 1621 rendeu a Macau 60000 cruzados em fretes.

No contexto dos acontecimentos que aqui registamos dom Francisco de Mascarenhas tomou posse em 17 de Julho de 1623 como primeiro capitão-geral ou governador de Macau.

Apesar dos insistentes pedidos dos comerciantes de Macau para a legalização do comércio com Manila a partir de 1623 eles não foram aceites pelo vice-rei do Estado da Índia, que por decisão tomada em 17 de Abril de 1624 continuou a não autorizar a legalização de tais trocas, pois se o fizesse iria contra as ordens do rei. Esta rejeição, contudo, não teve efeitos práticos, pois não era possível evitar a tendência do aumento de negócios e da cooperação defensiva entre Macau e as Filipinas. O vice-rei dom Francisco da Gama constatou explicadamente essa situação ao registar em carta de 15 de Março de 1623 a "devassidão com que está aberto e se continua o trato entre a cidade de Macau e a de Manila". Esta realidade exigia "se atalhar a independência que o Estado da Índias Ocidentais poderá ficar tendo de Espanha, se mui rigorosamente e apertadamente se lhe não impedir e com efeito tirar este comércio de Macau". ${ }^{49}$ De assinalar esta precoce noção de "independência" americana.

\footnotetext{
46 Arquivo português oriental, fascículo 6, 1875, págs. 1206-1207.

47 Videira Pires, Benjamim: A viagem de comércio.., pág. 19.

48 Ibidem, págs. 19-20.

49 Documentos remetidos da India ou livro das monções, volume IX, págs. 190-191.
} 
O relacionamento e aproximação luso-espanhola na Ásia Oriental era de tal forma notória que em 1625, por exemplo, Macau conseguia pagar grande parte das suas dívidas devido aos 40000 xerafins que lhe havia rendido a viagem a Manila. ${ }^{50}$ Nesta cidade continuou a registar-se a presença de navios de Macau, nomeadamente cinco em 1627 e dois em 1628. Face a este crescimento de tráfico incontrolável o vice-rei o Estado da Índia dom Miguel de Noronha, conde de Linhares, ao sair de Lisboa em Abril de 1629 levou instruções no sentido de legalizar em determinadas condições as viagens entre Macau a Manila, tendo em 16 de Novembro de 1629 o Conselho do Governo e Fazenda em Goa realizado um leilão para a venda de viagens por três anos de Macau a Manila. ${ }^{51}$ Os procuradores da cidade de Macau não concordaram com o elevado preço proposto para essa venda e por isso as viagens foram compradas por Lopo Sarmento de Carvalho em 28 de Novembro, juntamente com três viagens ao Japão, pagando por todas elas a quantia de 306000 xerafins, a qual foi paga mediante uma forma complexa e que veio a gerar alguma controvérsia, mas que é reveladora do elevadíssimo poder económico daquele que era então o mais poderoso magnate português na Ásia e havia sido o capitão de Macau quando sofrera o ataque dos holandeses em 1622.

Ao alcançar o monopólio destas viagens Lopo Sarmento de Carvalho comprometeu-se a enviar para cada um dos locais indicados três navios por ano ou de qualquer forma nove durante a vigência do contrato. $O$ senado de Macau ficou desagradado com este negócio e acabou por inviabilizar a realização das referidas viagens a Manila nos anos seguintes, as quais foram feitas por mercadores de Macau com seis navios em 1630, e três em 1631.

As três viagens de Lopo Sarmento de Carvalho a Manila acabaram por ser realizadas entre 1632 a 1634 sob a direcção do seu cunhado e associado António Fialho Ferreira, na sequência do apelo que teve de fazer à intervenção do vice-rei, que então nomeou Manuel da Câmara de Noronha para capitão-geral de Macau. Esta realidade revela o ambiente que se vivia nesta cidade entre grupos económicos rivais.

Em 14 de Março de 1632, foi de novo proibida a venda das viagens de Manila, e em 20 de Dezembro de 1632, Filipe III de Portugal enquanto pedia ao conde de Linhares que estivesse em aliança com o governador de Manila para desalojar os holandeses da ilha Formosa, insistia no corte total

50 Videira Pires, Benjamin: A viagem de comércio..., pág. 22.

51 Sobre estas viagens e negócios que aqui resumimos ver Boxer, Charles R.: $O$ grande navio de Amacau, págs. 100-122 e Videira Pires, Benjamim: A viagem de comércio... págs. 23-24. 
da comunicação e comércio entre a China e Manila, para assim evitar os grandes inconvenientes que daí resultavam aos Estados das Índias Orientais e Ocidentais.

O conde de Linhares informava por seu lado o rei em 6 de Outubro de 1633 que tinha cumprido a ordem dada para arrendar as viagens de Macau para Manila, por conta da Fazenda Real e que quanto à ordem para se cerrar aquele comércio avisou que já tinha enviado para a China todos os papéis necessários para esse efeito, referindo que mesmo concordando ser a separação do comércio entre as Índias Orientais e Ocidentais muito conveniente, não podia responder pelo lado de Espanha, pois os castelhanos tinham grande interesse naquelas viagens, entendendo por isso que el-rei devia pelo lado da coroa de Castela insistir nessas medidas.

Nesta altura assistem-se a atitudes descoordenadas e repetitivas em insistências que revelam um certo desnorte das iniciativas entre a Europa e a Ásia, pois vindo uma carta régia datada de Lisboa em 28 de Fevereiro de 1633 proibir de novo o comércio de Manila para Macau, tornando o vicerei responsável pela rigorosa execução desta ordem, este respondeu em Goa a 28 de Novembro de 1634 com a alegação de que junto remetia a cópia da ordem régia que estabelecia que as viagens de Macau para Manila fossem por conta da Fazenda Real e afirmando ter cumprido tudo que sobre esta matéria fôra determinado. ${ }^{52}$

A coroa esforçava-se em vão por contrariar as solicitações que a câmara de Macau continuava a fazer, facto que é referido ao vice-rei pela carta régia de 9 de Março de 1634, na qual se registou o indeferimento da petição que aquela tinha feito relativamente às viagens a Manila, recomendando ainda que o conde de Linhares fizesse guardar as proibições que diziam respeito àquele comércio. Por essa altura o vice-rei comunicou ao rei que embora desejasse cumprir as suas ordens quanto à extinção destas viagens, não vê possibilidade de o fazer, por os chineses terem que dar vazão à sua seda, tanto mais que se lhes oferecia oportunidade por muitas e diferentes vias. Não vê também possibilidade de evitar as facilidades dadas aos chineses, não só por serem feitas por vassalos seus, mas principalmente porque está averiguado que ainda que se trabalhasse por encerrar este comércio, nunca se conseguiria por via de Manila. Com efeito os castelhanos, ao verem que lhes começava a faltar a seda, mandavam embarcações buscá-la com o pretexto de obterem provisões. Como de nenhuma maneira se podia

52 Boletim da Filmoteca Ultramarina Portuguesa, n. ${ }^{\circ} 10$, 1958, págs. 364-365. 
impedir este comércio, parecia muito conveniente e justo que o rei obtivesse algum proveito com elas, quanto mais não fosse para a manutenção de Macau. Quanto ao que tocava ao contrato de Sevilha que o rei fizera com o intento de proibir o dito comércio, fica de momento remediado, por se haver mandado que no pataxo para Manila não fossem mais sedas nem especiarias que as que fossem necessárias para o gasto local. Em Macau, o capitãogeral da cidade Manuel da Câmara de Noronha escreveu por seu lado ao vice-rei conde Linhares em 12 de Setembro de 1633 tratando das relações que ali se mantinham com Manila, informando-o nomeadamente dos navios que anteriormente tinham partido de Goa para Macau, explicando a razão por que na carga dos navios a seguir para Manila favoreceu os castelhanos, deixando-os embarcar as suas fazendas em primeiro lugar, o que muito tinha aborrecido o capitão António Fialho Ferreira; indicou ainda que nessa altura o comércio de Portugal com o Japão corria grande risco, pela insistência que os holandeses faziam naquelas paragens, pagando percentagens maiores e oferecendo aos governadores ricos presentes para lhes ganharem a simpatia, explicando que os moradores de Macau deviam dinheiro aos japoneses e que se o comércio parasse, pereceria todo o povo da cidade, visto que não ter mais por onde se pudesse manter. O capitão informava ainda que tivera notícia de que muitos mercadores de Macau com receio dessa proibição começaram a comerciar com Manila, navegando par esse efeito em pequenos barcos e que estava impossibilitado de os prender ou castigar, visto encontrar-se sem presídio e os chineses lhes darem protecção, pelo que acabava o rei por ficar pior servido e arriscava a vida de uma cidade e de seus vassalos, podendo tirar dela largos proventos. ${ }^{53}$

Em 1635, António Bocarro enviou a Filipe III um amplo e rigoroso panorama do Estado da Índia que traçara no ano anterior num Liuro das plantas de todas as fortalezas, Cidades, e povoaçõis do estado da India Oriental, no qual registou entre outras indicações sobre as actividades económicas centradas em Macau aquelas que eram relativas às Filipinas:

"As outras viagens que se fazem da China, uma é a de Manila porque, ainda que sua majestade ordenou que se não fizessem, porque se não levassem a Nova Espanha as sedas da China, com que se ficava perdendo o contrato de Sevilha, contudo, considerado como nunca haviam de deixar de se mandar à formiga alguns chós dos casados da China, em que só a Fazenda de sua majestade ficava perdendo, e que, juntamente, os provimentos de munições pera que sua majestade só dava lugar de se virem buscar de

53 Ibidem, n. ${ }^{\circ} 12,1959$, págs. 348-350. 
Manila à China se haviam de mandar trazer por um galeão de castelhanos, que sempre havia de levar o restante carregado de sedas, por mais proibições e guardas que nisso se pusessem, ordenou o conde de Linhares, viso-rei que se levassem os ditos provimentos todos os anos a Manila, conforme a lista que o governador de Manila mandasse, por um pataxo pequeno, que fosse de Macau, e o restante de sua carga fosse de peças de muita valia, das que servissem pera o uso e vestir da Manila, pera que se não pudesse levar nada a Nova Espanha e se ficasse a Fazenda de sua majestade aproveitando dos fretes pera o pagamento do presídio da cidade de Macau, como largamente se contem no dito regimento, a qual viagem poder vir a render trinta mil patacas, pouco mais ou menos, correndo por pessoas diligentes e desinteressadas, donde se hão-de tirar os gastos que sempre serão de três mil quinhentos ate quatro mil patacas. ${ }^{54}$

\section{Questões políticas e religiosas no relacionamento luso-espanhol em torno das Filipinas e da China}

Da entre a abundante documentação espanhola relativa à problemática aqui focada podemos apontar apenas a título de exemplo que em 26 de Setembro de 1632 foi formulado o pedido à Real Audiência, em funções de governo de Manila, para que fizesse acabar o trato dos portugueses de Macau nessa cidade e que em 7 de Outubro de 1634, dom Juan Grau, procurador geral de Manila, escreveu um memorial sobre os graves danos que resultavam da contratação que os portugueses tinham estabelecido naquela cidade. É de assinalar que em 1635 foram quatro navios de Macau a Manila e que esta tinha então Juan Battista Roman como seu feitor em Macau.

As Filipinas dividiram as opiniões dos espanhóis que sobre estas ilhas se expressaram em atitudes desencontradas..$^{55} \mathrm{Um}$ dos casos mais radicais encontra-se na proposta do dominicano Diego Aduarte que em 1618 pediu a Filipe III de Espanha para mandar evacuar Macau e enviar os portugueses que aí estavam para a Índia, concentrando em Manila o comércio com o Japão, de onde os espanhóis das Filipinas obteriam a prata, em vez de a retirarem do México. Contrária a esta posição foi a do parecer igualmente radical expresso por Hernado de los Rios Coronel no seu Memorial, y relacion para sv magestad impresso em Madrid em 1621, no qual se defendia a possibilidade de a coroa de Castela trocar as Filipinas pelo Brasil da coroa de Portugal. Curiosamente o que veio a acontecer foi o contrário do

54 Livro das plantas de todas as fortalezas, cidades e povoações do Estado da Índia Oriental, edição de Isabel Cid, Imprensa Nacional-Casa da Moeda, Lisboa, 1992, volume 2, pág. 270.

55 Videira Pires, Benjamin: A viagem de comércio..., págs. 27-28. 
que está expresso nesta última proposta, pois só quando foi assinado em 1750 o tratado de Madrid para a demarcação das fronteiras do Brasil a coroa de Portugal reconheceu formalmente à de Espanha o direito à posse das Filipinas e apenas mediante a cedência dos direitos que os espanhóis tinham aos territórios do interior do Brasil, os quais haviam entretanto sido ocupados pelos portugueses ao longo dos séculos XVII e XVIII.

Paralelamente aos debates luso-espanhóis de natureza económica e política surgiram também controvérsias de cariz religioso que passaram pela defesa dos interesses do Padroado Português do Oriente em territórios da China e do Japão, os quais foram insistentemente defendidos pelos jesuítas em Madrid e Roma, contra o empenho de eclesiásticos espanhóis ligados às Filipinas, que queriam ir missionar para essas regiões.

Em 1585, agostinhos espanhóis, seguidos por dominicanos, vindos das Filipinas começaram a estabelecer-se Macau, mas logo nos anos seguintes foi ordenado que as igrejas por eles iniciadas deveriam ficar unicamente sob a alçada de eclesiásticos do Padroado português. Contrariando estas determinações franciscanos espanhóis seguidos por membros de outras ordens com a mesma nacionalidade acabaram por conseguir autorizações, sobretudo a partir de inícios do século XVII, para missionar no Japão, entrando em graves quezílias com os jesuítas que defendiam a preponderância do Padroado português. Esta situação conflituosa acabou em 1614 com a proibição rigorosa da presença de sacerdotes católicos no Japão. A prática da religião cristã foi desde então severamente punida naquele arquipélago, o que deu origem à ocorrência de numerosos martírios por parte daqueles que desafiavam a lei. É neste contexto que merece ser assinalado um fenómeno de natureza religiosa que se prende à história das relações entre Macau e Manila.

Na segunda metade do século XVI e nos inícios do século XVII, quando as relações entre Macau e Nagasaqui prosperavam, tanto no plano económico como no da expansão do cristianismo, foram de Lisboa para Macau e o Japão numerosos jesuítas, de que aqui retemos apenas o exemplo de Sebastião Vieira. ${ }^{56}$ Este padre foi para Macau em 1603 e no ano seguinte para Nagasaqui, repartindo-se de seguida em estadias nestas duas cidades. Em 1614, Sebastião Vieira foi um dos que teve de abandonar Nagasaqui,

56 Sobre este autor e a sua obra véase Franco, António: Imagem da virtude em o Noviciado da Companhia de Jesus: no Real Colégio de Coimbra, na Oficina da Universidade, Évora, 1719, tomo I, págs. 156-187 e Schütte, Josef Franz: Monumenta Historica Japoniae, Monumenta Historica Societatis Iesu, volume 111, Roma, 1975, I, págs. 1323-1324. 
indo para Manila, na expectativa de conseguir regressar logo de seguida ao Japão, mas não o tendo podido fazer acabou por voltar a Macau. Este activo jesuíta depois de uma ida à Europa veio de novo para esta cidade, onde acabou por não permanecer muito tempo, pois estava possuído de uma grande vontade de ir para o Japão e aí continuar a missão de evangelização, ainda que soubesse estar condenado ao martírio. Para poder concretizar esse desejado regresso Sebastião Vieira foi para Manila, de onde em 1632 partiu clandestinamente para Nagasaqui, acabando por ser preso e executado em Endo (Tóquio) a 6 de Junho de 1634. Antes que tal acontecesse este jesuíta ainda escreveu em 18 de Fevereiro de 1633 uma relação das viagens que fez entre Macau, Manila e o Japão, a qual ficou manuscrita.

A estranha ânsia de martírio que então foi sentida por muitos religiosos verificou-se não apenas em portugueses que haviam ido para Macau pela rota do cabo da Boa Esperança, mas também em alguns dos poucos portugueses que haviam ido pela rota de Acapulco para as Filipinas, como aconteceu com Frei Vicente de Santo António. ${ }^{57}$ Este sacerdote foi ordenado em Lisboa em 1617, partindo depois para Espanha e daí para o México, em 1619, onde ingressou na Ordem dos Agostinhos, seguindo em 1621 para Manila. Em 1622, Frei Vicente de Santo António conseguiu ir clandestinamente para o Japão introduzindo-se junto dos cristãos que aí lutavam pela sobrevivência da sua religião, mas acabou por ser preso em 25 de Novembro de 1629, sofrendo o martírio em 3 de Setembro de 1632.

Nesta evocação de viajantes eclesiásticos que andaram por Macau e Manila, tendo deixado os seus preciosos testemunhos vivenciais sobre essas paragens, assinalamos ainda o caso de Frei Sebastião Manrique, um outro agostinho que tinha a intenção de seguir os exemplos dos mártires que então iam tombando no Japão e tanta comoção provocavam nos cristãos de todo o mundo ${ }^{58} \mathrm{Na}$ história que este frade fez do seu itinerário registou que estando em Goa em 1637 decidiu partir numa missão de evangelização no Japão. Para a concretizar ele sabia que só o poderia fazer por via das Filipinas, na medida em que estava impedido de seguir pela via de Macau, pois os comerciantes portugueses que então ainda iam desta cidade para Nagasaqui estavam rigorosamente proibidos desde 1614 de levar religiosos para o arquipélago nipónico. Antes de iniciar a sua viagem em

57 Sobre este autor ver Cartas do Japão: a alma dum Santo revelada em suas cartas, introdução, tradução e notas de José Cabrita, Faro, s.n., 1967.

58 Consultámos a obra deste autor publicada em 1649 na edição de Luís Silveira, Itinerário de Sebastião Manrique, Agência Geral das Colónias, Lisboa, 1946, 2 volumes. 
27 de Abril de 1637 Frei Sebastião Manrrique recebeu correspondência do vice-rei do Estado da Índia para entregar ao governador das Filipinas. O nosso frade passou por Malaca, onde chegou em 11 de Junho, e daí seguiu em 16 de Agosto num navio comandado por António Pais Brandão que entrou no porto de Cabite em 5 de Setembro.

Frei Sebastião Manrrique foi muito bem recebido em Manila pelos portugueses que ali se encontravam, de entre os quais se destacava dom Diogo Miranda. Este fidalgo tinha ido para ali três anos antes como capitão-mor de uma armada de Macau, tendo sido na sua companhia e na de António Pais Brandão que Frei Sebastião Manrrique foi visitar o governador de Manila, a quem entregou a correspondência que levara de Goa, sendo informado que ia seguir para Macau um galeão com os portugueses que ali se encontravam. O agostinho, contudo, teimou na sua missão e permaneceu em Manila a tentar encontrar um navio que o levasse ao Japão, mas quando estava prestes a lograr o seu objectivo chegaram a Manila galeotas de Macau tendo por capitão-mor Aleixo de Mesquita. Este português insistiu junto do governador no sentido de não deixar seguir qualquer religioso das Filipinas para o Japão, pois as autoridades locais haviam avisado expressamente os portugueses de que haveria severas punições caso ali chegasse algum religioso vindo de Manila. Perante esta situação Frei Sebastião Manrique foi obrigado a desistir do seu projecto nipónico e foi para Macau. Depois de uma estadia nas Filipinas que durou catorze meses o agostinho embarcou em 13 de Outubro de 1638 com esse propósito num pataxo de Gaspar Borges da Fonseca, que havia chegado a Manila proveniente do Camboja. A viagem, contudo, não correu bem, pois a embarcação foi parar à Cochinchina, tendo Frei Sebastião Manrique chegado a Macau apenas em 29 de Maio de 1639, aí permanecendo até 29 de Janeiro de 1640, tendo ainda assistido ao regresso dos últimos portugueses que haviam ido ao Japão antes do envio da chamada "embaixada mártir", que partiu de Macau para Nagasaqui em 22 de Junho de 1640.

\section{A Restauração portuguesa e o fim das relações entre Macau, as Filipinas e o Japão no século XVII}

O tema da legalidade da realização do comércio entre Macau e Manila mantinha-se vivo na conjuntura que estamos a abordar, pois as autoridades de Macau voltaram a solicitar como já era hábito o fim da proibição da ida 
a Manila, como se verifica pelo teor da carta que em 31 de Agosto de 1638 foi enviada para Lisboa pelo vice-rei do Estado da Índia, dom Pedro da Silva. A coroa portuguesa, apesar de se aperceber da situação desesperada de Macau, limitou-se a declarar em 18 de Março de 1640, através de donha Margarida, duquesa de Mântua, que ia ponderar acerca do levantamento da proibição do comércio de Manila com Macau, mas que até lá deviam cumprir-se as ordens anteriores..$^{59}$

Entretanto em Goa, antes de a 8 de Setembro de 1641 aí se saber da aclamação de dom João IV como rei de Portugal, o vice-rei conde Aveiras insistiu por carta de 2 de Agosto de 1641 junto de Filipe, que ainda pensava ser III de Portugal e IV de Espanha, no sentido de que teria toda a conveniência em não proibir o comércio de Macau com Manila, pois o contrato das sedas de Sevilha, que estava na origem desta proibição, não era tão importante como o comércio da China, e a prata de que Macau tinha necessidade apenas podia vir de Manila, visto não haver esperanças de que ela voltasse a ser fornecida pelo Japão. $\mathrm{O}$ vice-rei lastimava por fim a falta de socorros que não the foram enviados, facto que levara à recente perda de Malaca e facilitava a fixação dos holandeses no Oriente. Com a mesma data o vice-rei enviou uma outra carta reforçando a posição de Macau, pois referia que, atendendo a que esta cidade estava muito prejudicada por os holandeses lhe terem impedido o comércio com o Japão, pediam os seus moradores que lhes fosse concedido um meio para negociarem as sedas da China que tinham em grande abundância, pois a proibição que se lhes fazia de comerciarem com Manila só contribuiria para afastar todos os moradores da cidade e coroar de êxito os desejos dos inimigos. Nessa carta acrescentava-se ainda que se tiravam grandes lucros das alfândegas de Macau, pelo que o rei teria a maior conveniência em enviar socorros para defesa daquela região. ${ }^{60}$

O governador das Filipinas, Sebastián Hurtado de Corcuera, por seu lado, afirmava ao rei que em 1640 estava a cumprir as determinações régias de proibição das relações entre as Filipinas e Macau, lembrando que em 1635 quando viera para as Filipinas encontrara ali três navios portugueses, mas que naquele ano apenas autorizara a vinda de um navio de Macau para trazer armamento, de que ali havia falta. A ida de tal navio em 1640 está confirmada, sabendo-se por um registo do senado de Macau datado de 12

59 Boletim da Filmoteca Ultramarina Portuguesa, n. ${ }^{\circ}$ 13, 1959, pág. 697.

60 Ibidem, n. ${ }^{\circ} 20,1962$, págs. 159-160. 
de Novembro desse ano que a viagem a Manila foi feita por Miguel de Macedo, que dali trouxe mais de 8000 pardaus. ${ }^{61}$

Na prática a proibição das viagens em causa continuou a não ser cumprida, sabendo-se que em 1641 foram de Macau a Manila pelo menos dois navios, um dos quais anunciando a perda e Malaca em 14 de Janeiro de 1641, e outro em 1642.

Viviam-se então tempos difíceis em Macau na sequência do termo das relações com o Japão em 1639, as quais haviam sido a principal razão de ser da criação dessa cidade e haviam permitido a realização de negócios muito lucrativos. A agudização das tensões luso-nipónicas que se tinham vindo a acentuar nas décadas anteriores foram acompanhadas pelo agravamento dos ataques dos holandeses, os quais culminaram com a conquista de Malaca em 1641.

O sistema das relações mercantis dos portugueses na Ásia Oriental e no Sudeste Asiático estabelecido numa base quadrangular tendo por pólos principais Malaca, Macau, Nagasaqui e Manila estava a entrar em colapso, pois tendo ruído já os pólos de Nagasaqui e Malaca, em 1642 caiu o pólo de Manila. Com efeito a completar o encadeado dramático desta fase da História de Macau ocorreu então o fim do relativamente bom relacionamento luso-espanhol que havia sido alcançado no eixo Macau-Manila nas décadas anteriores, o qual quase fazia lembrar de alguma forma a fase que ocorrera sessenta anos antes, quando se tinham iniciado. Esse fim algo inesperado das relações luso-espanholas surgiu na sequência do golpe de Estado seccionista levado a cabo em Lisboa em 1 de Dezembro de 1640, o qual dera a coroa de Portugal a dom João IV, tirando este reino e os seus domínios ultramarinos da órbita do poder de Filipe IV de Espanha, que deixava assim de ser Filipe III de Portugal. A notícia deste evento foi trazida de Lisboa e transmitida em Macau no dia 31 de Maio de 1642 por António Fialho Ferreira, tendo nesse mesmo dia sido prestado o juramento de obediência ao novo rei pelas figuras mais proeminentes que então se encontravam em Macau. É de assinalar aqui como os ventos da História por vezes mudam subitamente, pois poucos dias antes, a 15 de Abril de 1642, o senado de Macau autorizara o envio de armamento para Manila. ${ }^{62}$

Quando em Manila se teve notícia da Restauração, o que aconteceu depois de se ter sabido de tal acontecimento em Macau, os interesses desta cidade eram ali assegurados pelos seus procuradores Jacinto Guterres de

61 Videira Pires, Benjamim: A viagem de comércio..., pág. 30.

62 Ibidem, pág. 30. 
Brito, Matias Ferreira de Proença e Manual Matos de Siqueira, os quais simularam então fidelidade a Filipe IV de Espanha, pois de outra forma não conseguiriam regressar a Macau com as suas fazendas, que ascendiam ao montante de 434614 pesos. Essas personalidades partiram de Manila para Macau em dois navios acompanhados por um terceiro, que foi armado pelo governador das Filipinas, dom Sebastian Hurtado de Corcuera, no qual investiu 38127 pesos, nele tendo feito seguir cinquenta soldados espanhóis comandados pelo capitão dom Juan Claudio Verástegui, que deveria substituir dom Sebastião Lobo da Silveira, nessa altura capitão-geral de Macau. Quando os espanhóis chegaram a Macau viram que aqueles procuradores e a cidade tinham aderido à Restauração, mas apesar de tal atitude os portugueses respeitaram-nos e só alguns meses depois é que surgiram reacções negativas para alguns deles, pelo que acabaram por ser presos e remetidos uns para Manila e outros para Goa. Quando Luís de Carvalho de Sousa chegou a Macau em 14 de Junho de 1644 para assumir as funções de capitãogeral já ali não havia qualquer espanhol. ${ }^{63}$

A situação de Macau no período correspondente ao dos primeiros tempos da Restauração foi particularmente delicada, como o sabia o jesuíta António Francisco Cardim que deixara Macau em 1640 para ir a Lisboa, cidade onde num memorial apresentado em 6 de Dezembro de 1642 alertou dom João IV sobre a situação de Macau, nele manifestando o receio de que a cidade se pudesse manter fiel a Filipe IV, caso os seus habitantes "não fossem levar fazenda aos castelhanos, como costumavam todos os anos, que importam dous milhões de ouro". ${ }^{64} \mathrm{O}$ patriotismo dos portugueses de Macau, contudo, falou mais alto e consentiram em abdicar de uma actividade económica ilegal, a que até aí haviam recorrido, sendo de notar que em 1640, de acordo com uma prática que se vinha repetindo desde 1623, o senado ainda insistira junto de Madrid no sentido de que fosse revogada a proibição sempre repetida de legalizar o comércio com Manila. Os comerciantes de Macau ao não reconhecerem o rei de Espanha como senhor da sua cidade perdiam assim os benefícios que até aí haviam usufruído, mas a ruptura de relações entre Portugal e Espanha vinha afinal e na prática concretizar a sempre repetida proibição do comércio entre Macau e Manila, ainda que não fosse normalmente respeitada, sobretudo nos últimos anos, mesmo que por vezes tivesse restringido as suas actividades.

63 Conde da Ericeira, História de Portugal restaurado, edição de António Álvaro Dória, Civilização, Porto, 1945, volume II, págs. 108-109.

64 Boxer, Charles R.: Macau na época da Restauração..., págs. 145-152. 


\section{Macau-Filipinas: um tipo de relacionamento entre o proibido e o consentido}

A realidade da rota Macau-Manila, considerada ilegal mas na prática seguida de forma mais ou menos tolerada, constitui um fenómeno a realçar na História das Expansão Portuguesa no Oriente que deve ser colocado em paralelo com o comércio oficial que se realizava sob o controlo da coroa e o comércio livre que os portugueses faziam em muitos locais sem intervenção da coroa.

Em 1642, a menos de um século do início da presença pioneira dos portugueses em Macau, acabava a parte mais brilhante da História de sucesso desta cidade, a qual declinou ao terminar as suas relações com as Filipinas, logo a seguir ao fim do comércio com o Japão e Malaca. A notável capacidade de sobrevivência demonstrada pelas gentes de Macau a partir de então corresponde a uma outra história de sucesso, ainda que sem o brilho anterior, por entretanto terem desaparecido os factores excepcionalmente favoráveis que haviam dinamizado e dado um protagonismo a Macau numa fase em que a sua acção foi particularmente marcante na História das ligações entre o Ocidente o Oriente.

Após o fim das relações directas entre Macau com Manila, o comércio entre estas cidades ainda se processou durante alguns anos de forma indirecta a partir de Macassar, pois nessa cidade da ilha indonésia de Sulawesi fizeram-se negócios dinamizados por portugueses e mestiços que para ali tinham fugido de Malaca em 1641, os quais mantinham relações com Macau.

Após o termo da guerra da Restauração dom Pedro II escreveu em 28 de Março de 1668 uma carta ao vice-rei do Estado da Índia pedindo-lhe para fazer diligências no sentido de verificar se seria possível restabelecer as relações entre Macau e Manila. No cumprimento dessas ordens dom Luís de Mendonça Furtado e Albuquerque, conde de Lavradio, nomeou em 27 de Abril de 1672 para essa missão uma "junta”, presidida por António Barbosa Lobo, que era o novo capitão-geral de Macau. Os resultados desta tentativa de reatamento da viagem Macau-Manila não foram positivos pois em 23 de Janeiro de 1677 o vice-rei dom Pedro de Almeida Portugal, conde de Assumar, informava o rei que o capitão-geral e os oficiais da câmara de Macau o tinham avisado de que o governador das Filipinas, Manuel de León, depois de ter autorizado uma viagem proibiu a ida a Manila de qual- 
quer navio de Macau. Só a partir de 1684 é que há registo de novas deslocações de navios de Macau a Manila, reiniciando um relacionamento que nos anos seguintes ainda contou com algumas vicissitudes. ${ }^{65}$

A partir dos finais do século XVII, com algumas interrupções, navios de Macau e de Manila foram fazendo um comércio relativamente regular e pacífico entre as duas cidades, o qual se processou sem grande notoriedade e proveito, mas num nível suficiente para manter aberta e viável a ligação entre as duas cidades, nem que mais não fosse para trazer a Macau o arroz necessário ao alimento dos seus habitantes.

De uma forma quase simbólica terminamos estas breves observações sobre alguns dos tópicos mais significativos da História das relações entre Macau e as Filipinas evocando o acto que consistiu na recolha feita em 14 de Março de 1761 pelo jesuíta português João Álvares de uma parte preciosa dos documentos de Macau e do Japão. ${ }^{66}$ Esses documentos foram colocados em quatro caixas de madeira então foram enviadas para Manila, ao cuidado do padre Ignacio Málaga, procurador da província jesuítica das Filipinas, tendo de seguida sido remetidas em 1773 para Madrid, onde se encontram, contribuindo assim discretamente para salvaguardar a memória de um passado que importa manter vivo no nosso conhecimento.

Recibido 8 de mayo de 2008 Aceptado 4 de noviembre de 2008

65 Videira Pires, Benjamim: A viagem de comércio..., págs. 35-37

66 Ibidem, pág. 64. 